\title{
Eriyik Yığma Modellemesi Esaslı Üç Boyutlu (3B) Eklemeli Üretim Tekniği Kullanılarak Poliüretan Malzemeden Bir Yapay İnsan Kulak Kepçesi Üretimi
}

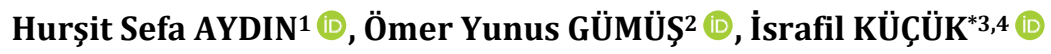 \\ ${ }^{1}$ Bursa Teknik Üniversitesi, Fen Bilimleri Enstitüsü, Malzeme Bilimi ve Mühendisliği Bilim Dalı, 16290, Bursa, \\ Türkiye \\ ${ }^{2}$ Bursa Teknik Üniversitesi, Mühendislik ve Doğa Bilimleri Fakültesi, Lif ve Polimer Mühendisliği Bölümü, 16290, \\ Bursa, Türkiye \\ ${ }^{3}$ Bursa Teknik Üniversitesi, Mühendislik ve Doğa Bilimleri Fakültesi, Metalurji ve Malzeme Mühendisliği Bölümü, \\ 16290, Bursa, Türkiye \\ ${ }^{4}$ Gebze Teknik Üniversitesi, Nanoteknoloji Enstitüsü, Nanobilim ve Nanomühendislik Anabilim Dalı, 41400, \\ Gebze, Türkiye
}

(Alınıș / Received: 14.03.2019, Kabul / Accepted: 20.08.2019, Online Yayınlanma / Published Online: 30.08.2019)

Anahtar Kelimeler

3B baskl,

EYM,

Yapay organ,

Poliüretan
Özet: Son yıllarda 3B baskı teknolojileri sahip olduğu yüksek üretim hızı, uygun maliyeti ve biyouyumlu malzeme üretimine imkan veren özellikleriyle yapay organ geliştirme alanına önemli yenilikler getirmiştir. Bu çalışmada, eriyik yığma modellemesi (EYM) özelliğine sahip bir 3B yazıcı kullanarak poliüretan (PU) polimeriyle hacimsel olarak farklı doluluk oranlarında (\%25, \%50, \%75 ve \%100) yapay insan kulak kepçesi üretimi gerçekleştirilmiştir. Kimyasal yapı analizleri için Fourier dönüşümlü kızlötesi (FTIR) spektroskopisi, termal analizler için termogravimetrik analiz (TGA) cihazı, yüzey görüntülerini incelemek için stereomikroskop ve taramalı elektron mikroskobu (SEM), mekanik ölçümler için sertlik ve çekme testi cihazları kullanılmıștır. Geliştirilen yapay kulak kepçelerinden en uygun tasarımın \%50 doluluk oranına sahip olan kulak tasarımı olduğu belirlenmiştir.

\section{Production of an Artificial Human Auricle from Polyurethane by Using Three Dimensional (3D) Additive Manufacturing Technique Based Fused Deposition Modelling}

\section{Keywords}

3D printing,

FDM,

Artificial organ,

Polyurethane

\begin{abstract}
In recent years, 3D printing technologies have brought significant innovations in the field of artificial organ development due to their properties such as high production speed, cost effective and enabling fabrication of biocompatible materials. In this study, artificial human auricles were produced in different infill rates $(25 \%, 50 \%, 75 \%$ and $100 \%)$ volumetrically with polyurethane (PU) polymer by using a 3D printer based on fused deposition modelling (FDM). Fourier transform infrared (FTIR) spectroscopy, thermogravimetric analyzer (TGA), stereomicroscope, scanning electron microscope (SEM), hardness tester and tensile test machine were used for chemical structure analysis, thermal analysis, surface images and mechanical measurements respectively. It was determined that the most suitable design among the developed artificial auricles is the auricle having $50 \%$ infill rate.
\end{abstract}

\section{Giriş}

Yapay organ kullanımı sayesinde kaza sonucu veya genetik deformasyondan kaynaklı fiziksel engelli bireylerin yaşam kalitesinde olumlu yönde gelişmeler (kendini eksik hissetmeme, toplum içerisindeyken özgüven artışı) meydana gelmektedir [1]. Son yıllarda estetiksel ve fonksiyonel olarak deri, kulak, burun gibi protezlerin kullanımını geliştirme çalışmaları yapılmaktadır [3]. Özellikle doku mühendisliği, ileri eczacılık gibi çeşitli alanlarda kullanılan 3B baskılama teknolojileri yapay organ elde edilmesine hızlı ve yüksek hassasiyette üretim, ek işlemlerin ortadan kaldırılması ve uygun maliyet gibi önemli avantajlar sağlamaktadır [1-3]. 1980'li yıllarda yaygın kullanımlarıyla büyük ilgi gören eklemeli imalat (EI) 
yöntemleri; eriyik yığma modelleme (EYM), seçici lazer eritme (SLE), seçici lazer sinterleme (SLS), stereolitografi (SLA) gibi başlıca üretim teknikleri olarak listelenebilir [4]. Esnek yapıların tasarımında malzeme kusurlarını azaltma özelliğiyle öne çıkan EYM, polimer ve polimer esaslı kompozit malzemeler için geliştirilmiş en yaygın kullanılan 3B eklemeli imalat yöntemidir [5]. Özellikle polilaktik asit (PLA), akrilonitril butadien stiren (ABS), polikarbonat (PC) ve poliüretan (PU) gibi polimerler düşük ergime sıcaklıklarına sahip olduklarından baskı malzemesi olarak tercih edilmektedir $[6,7]$.

Poliüretan türlerinden biri olan termoplastik poliüretan (TPU), sahip olduğu biyouyumluluk özelliğiyle tıbbi uygulamalarda yaygın olarak kullanılmaktadır[3, 8]. Sert ve yumuşak bölgelerden oluşan iki fazlı mikroyapısından dolayı kopolimer olarak adlandırılan TPU, mekanik özellikler açısından termoplastik malzemelere kıyasla yüksek uzama değerlerinin yanı sıra oldukça iyi çekme dayanımlarıyla ön plana çıkmaktadır $[3,6,8]$. Ayrıca TPU malzemeler düşük çapraz bağlanma derecelerine sahip olduklarından EYM sistemlerinde 3B yapı modelleri olarak üretilebilirler. Üstün elastisite ve termoplastik işlenebilirlik özelliklerinden dolayı, EYM teknolojilerinde kullanılan plastikleştirme etkisine dayalı fenomenlerden biri olan ekstrüzyonla katılaştırma tekniğiyle de üretilmeye uygun malzemelerdir [9].

EYM esaslı 3B yazıcıların üretim tekniğinin kolaylığı, üretimdeki yüksek hızı, düşük maliyet ve $3 B$ yazıcılara erişilebilirliği, 3B baskı tekniğinin eklemeli imalat yöntemlerinde en çok tercih edilen teknoloji haline gelmesi üretim sürecinin avantajlarıdır[10]. Karmaşık yapılı parçaların yüksek kalitede üretimine imkan sağlayan EYM yazıcılar, yüksek boyutsal hassasiyet gerektiren tıbbi implant, telekomünikasyon, elektronik ve havacılık gibi modern imalat endüstrisinde kullanılan malzemelerin elde edilmesini kolaylaştırmıștır. Bu 3B teknoloji sayesinde, imal edilen parçaların boyutsal stabilitesinin korunması ve tekrarlanabilirliği de sağlanmıştır [11]. EYM yöntemiyle elde edilen ürünlerin kalitesi büyük ölçüde seçilen üretim parametrelerine bağlıdır. SLS gibi eklemeli imalat yöntemlerine göre daha çeşitli üretim parametrelerine sahip olan EYM prosesi, üretilecek nihai ürünlerin boyutsal doğruluğunu da arttırmaktadır. Bu nedenle, üretim parametreleri ile boyutsal doğruluk arasında etkili bir ilişki kurmak ve optimum parametre ayarlarının belirlenmesi son derece büyük bir öneme sahiptir [12]. Yapılan çalışmalarda da son ürünlerin mekanik özellikleri; dolgu içeriği, baskı deseni, baskı hızı, tabaka kalınlığı ve doluluk oranı gibi baskı parametreleri ile düzenlenerek optimum değerlerde elde edilmiştir [6, $7,13]$. Ayrıca ülkemizde, EYM prosesi kullanılarak yapay organ üretimine yönelik yerli çalışmalar da gerçekleştirilmeye başlamıştır[14].
$\mathrm{Bu}$ çalışmada, esneklik ve biyobozunur özelliklere sahip olan TPU malzemesiyle EYM üç boyutlu yazıcısı kullanılarak yapay insan kulak kepçesi üretimi gerçekleştirilmiştir. Protez kullanımına yönelik geliştirilen kulak kepçeleri çeşitli doluluk oranlarında üretilmiştir. Elde edilen yapay insan kulak kepçelerinin yüzey ve mekanik özellikleri çeşitli karakterizasyon yöntemleriyle analiz edilmiştir.

\section{Materyal ve Metot}

\subsection{Materyal}

\subsubsection{Kullanılan filaman malzemeler}

Bu çalışmada Ultimaker firması tarafından üretilen ve ticari adı TPU 95A (Geldermalsen, Hollanda) olan termoplastik poliüretan (TPU) filamanı (yoğunluk = $1.22 \mathrm{gr} / \mathrm{cm}^{3}$, ergime sicaklığ $=220^{\circ} \mathrm{C}$, çap $=2.85 \mathrm{~mm}$ ) ile eSUN marka (Shenzhen, Çin) polilaktik asit (PLA) filamanı (yoğunluk $=1.20-1.25 \mathrm{gr} / \mathrm{cm}^{3}$, ergime sıcaklığ $1=190-220^{\circ} \mathrm{C}$, çap $=2.85 \mathrm{~mm}$ ) kullanılmıştır.

\subsubsection{Kullanılan 3B yazıcı}

Ayrıca üretilecek ana yapı baskısı ile destek yapı baskısına imkan veren çift püskürtme baskı ucuna sahip, katman kalınlığı minimum $20 \mu$ m olan baskıları gerçekleștirebilen, eriyik yığma modellemesi teknolojine sahip, ticari ismi Ultimaker 3 Extended (Geldermalsen, Hollanda) olan üç boyutlu yazıcısı kullanılmıștır.

\subsection{Metot}

\subsubsection{Boyutlu baskılama ve parametreleri}

Bu çalışmada, AUTODESK (Kaliforniya, ABD) yazılım firmasının bilgisayar destekli tasarım (CAD) programından geliştirdiği 3DS MAX yazılım modelleme programına aktarılarak hazırlanan insana özgü yapay kulak kepçesi modeli üretimi amaçlanmıştır. 3B baskı için (stl.) formatına dönüştürülen model dosyası da Cura (sürüm 2.7, Ultimaker, Geldermalsen, Hollanda) dilimleme yazılım programına aktarılmıștır. Şekil 1' de programa aktarlan 3B model geometrisi destek yapısı ile birlikte gösterilmiștir. Model ve destek malzemesinin baskı paramatreleri ile 3B yazıcının çalışma parametreleri belirlenerek baskılama işlemi başlatılmıştır. Şekil 2' de gerçekleștirilen üç boyutlu baskılama üretimine ait şematik gösterim görülmektedir. Baskı işlemi gerçekleştirilecek olan TPU ve destek malzemesi olan PLA filamanlar isitma bölgesine kadar $25 \mathrm{~mm} / \mathrm{sn}$ hızıyla beslenmiștir. Belirlenen baskılama sıcaklığı ile filamanlar eriyik hale getirilmiş ve isıtılan püskürtücü uca iletilerek baskılama tablası üzerinde tabaka tabaka ilerleyen 3B baskı üretimi gerçekleștirilmiștir. 


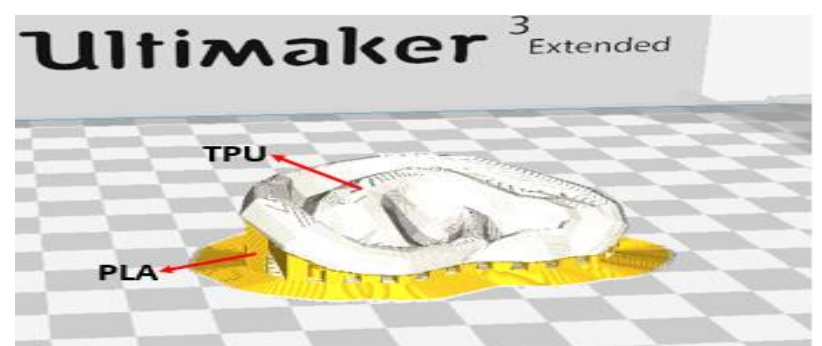

Şekil 1. Deneysel çalışmada kullanılan yapay insan kulak kepçesinin yazılım programına aktırılmış model görüntüsü

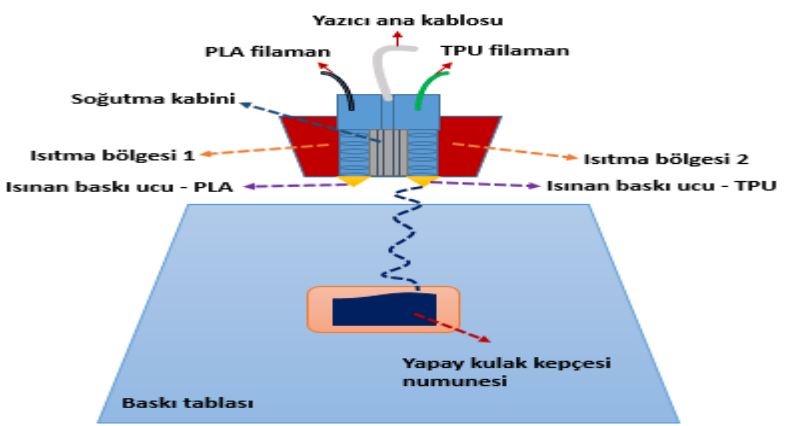

Şekil 2. Bu çalışmada kullanılan 3B baskılama işlemi ve yazıcı tasarımının şematik gösterimi

Bu çalıșmada yapay kulak kepçelerinin çeșitli doluluk oranlarında (\%25, \%50, \%75 ve \%100) üç boyutlu baskılama işlemi gerçekleştirilmiş olup kullanılan baskılama parametreleri Tablo 1' de sergilenmiștir. Tablo 2'de ise kulak kepçesi numunelerine ait değişen baskılama süreleri gösterilmiştir. Doluluk oranının artmasıyla birlikte 3B baskı üretimi için gereken süre de artmaktadır.

Tablo 1. 3B baskılama parametreleri

\begin{tabular}{ll}
\hline Baskı sıcaklığı & $228^{\circ} \mathrm{C}$ \\
Tabla sıcaklığ & $60^{\circ} \mathrm{C}$ \\
Baskı hızı & $25 \mathrm{~mm} / \mathrm{sn}$ \\
Duvar kalınlığ & $0,2 \mathrm{~mm}$ \\
Tabaka kalınlığ & $0,1 \mathrm{~mm}$ \\
\hline
\end{tabular}

Tablo 2. Farklı doluluk oranlarındaki TPU kulak kepçesi numunelerine ait baskılama süreleri

\begin{tabular}{ll}
\hline Doluluk oranı & Baskllama süresi \\
\hline$\% 25$ & 2 sa. 5 dak. \\
$\% 50$ & 2 sa. 20 dak. \\
$\% 75$ & 2 sa. 40 dak. \\
$\% 100$ & 2 sa. 55 dak. \\
\hline
\end{tabular}

\subsection{Filaman ve elde edilen kulak yapılarının karakterizasyon çalışmaları}

$\mathrm{Bu}$ çalışmada, geliştirilen yapay insan kulağı kepçesi üretimi sürecinde TPU filaman, 3B baskılama ile üretilen kulak numuneleri ve kulak numunelerine ait çekme test numuneleri üzerinden çeşitli karakterizasyon işlemleri gerçekleştirilmiştir. Kimyasal yapı analizleri için Bruker marka Optics Tensor37 (Massachusetts, ABD) model Fourier dönüşümlü kızlötesi (FTIR) spektroskopisi kullanılmıştır. Termoplastik poliüretana ait farklı karakteristik pik değerleri 500 ile $4000 \mathrm{~cm}^{-1}$ dalgaboyu aralı̆̆ında gözlemlenmiştir. Termal analizler için PERKIN ELMER marka STA6000 (Massachusetts, ABD) model termogravimetrik analiz (TGA) cihazı kullanılmıștır. Alümina kroze içerisine yerleştirilen TPU numune $10^{\circ} / \mathrm{dk}$ hız ile $900^{\circ} \mathrm{C}^{\prime}$ ye kadar isıtılmıştır. Yüzey görüntülerini incelemek için Leica marka M125 (Wetzlar, Almanya) model stereomikroskop ve JEOL marka JSM-6390LV (Tokyo, Japonya) model taramalı elektron mikroskobu (SEM) $10 \mathrm{kV}$ voltaj değerinde kullanılmıştır. Ayrıca mekanik ölçümler, AMITTARI (Guangzhou, Çin) marka sertlik test cihazı ve SHIMADZU marka AGS-X (Kyoto, Japonya) model çekme testi makinası ile gerçekleştirilmiştir. Deneysel çalışmada kullanılan TPU polimerinin sertlik ölçümü ASTM D2240 standatlarına göre yapılmıştır. Farklı doluluk oranlarına sahip TPU kulak kepçelerinin çekme testlerini gerçekleştirmek için TS EN ISO 527-2 standardına uygun olacak şekilde çekme numuneleri üretilmiştir. Üç boyutlu baskılama ile üretilen test numuneleri, oda sicaklığında ve $1 \mathrm{kN}$ yük kuvveti altında $300 \mathrm{~mm} / \mathrm{dk}^{\prime}$ lık çekme hızına maruz bırakılmıştır.

\section{Bulgular}

Ultimaker 3 Extended üç boyutlu yazıcı ile baskılama işlemi gerçekleştirilmiş çeşitli doluluk oranlarında (\%25, \%50, \%75 ve \%100) elde edilen nihai TPU kulak kepçesi numuneleri yapısal bütünlüğünü sağlayan PLA destek altlık malzemesiyle Şekil 3' te fotoğraflanarak sergilenmiştir. Değişen doluluk oranları üç boyutlu baskılamada görsel olarak yapısal bütünlüğü sağlayamama ve baskı hataları gibi farklılıklara sebep olmuştur. Yazılım programına aktarlan model geometrisi göz önünde bulundurulduğunda yapay insan kulak kepçesi formuna yüzey görünümü olarak en yakın baskılama $\% 50$ doluluk oranına sahip olan numunede gözlemlenmiștir.

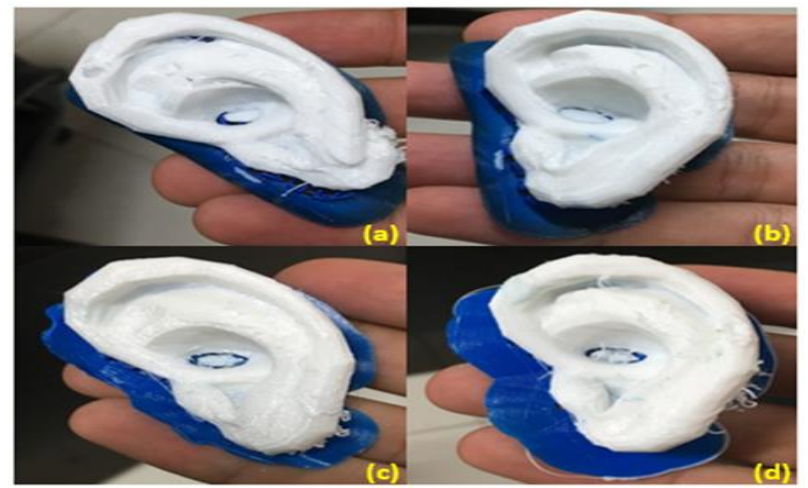

Şekil 3. Farklı doluluk oranlarında elde edilen TPU kulak kepçesi numunelerinin görüntüsü. (a) \%25, (b) \%50, (c) $\% 75$ ve (d) $\% 100$

3B yazıcıda baskılama işlemi gerçekleştirilecek olan TPU filaman ve baskllama sonucu üretilen yapay kulak kepçesine ait FTIR analizleri Şekil 4' te gösterilmiştir. Poliüretana ait olan $3332 \mathrm{~cm}^{-1}$ 
dalgaboyundaki pik, üretandaki $\mathrm{N}-\mathrm{H}$ grubunu (NHCOO-) temsil etmektedir. $2935 \mathrm{~cm}^{-1}$ dalgaboyundaki pik metilen grubunda $\left(-\mathrm{CH}_{2}\right)$ meydana gelen asimetrik titreşimleri ifade ederken, $2850 \mathrm{~cm}^{-1}$ dalgaboyuna ait olan pik $-\mathrm{CH}_{2}$ grubunda meydana gelen simetrik titreșimleri temsil etmektedir [15]. 1700 ve $1730 \mathrm{~cm}^{-1}$ dalgaboyunda bulunan pikler ise üretan bağına ait ve sırasıyla serbest ve hidrojen bağı (H-) yapmış karbonil grubuna $(\mathrm{C}=0)$ aittir [16]. Ayrica kullanılan TPU filaman içerisindeki $2329 \mathrm{~cm}^{-1}$ dalgaboyu ve civarındaki pikler, karbondioksit $\left(\mathrm{CO}_{2}\right)$ safsızlıkları olup 3B üretimin gerçekleștirilmesiyle ortadan kaldırılmıştır. FTIR analizleri ile belirlenen TPU' ya ait bu piklerin şiddeti polimer yoğunluğuna bağlı olarak artış göstermektedir [15]. Dolayısıyla elde edilen yapay insan kulak kepçelerinin kimyasal olarak üretime uygun olduğu FTIR analizleriyle anlaşılmaktadır.

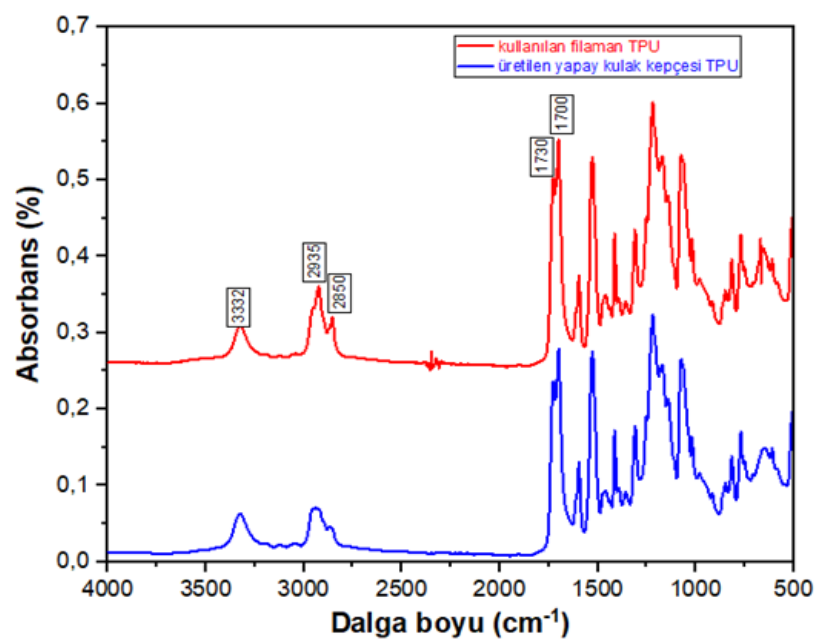

Şekil 4. Deneysel çalışmada kullanılan polimere ve üretilen kulak kepçesine ait karakteristik FTIR pikleri

3B baskılama üretiminde kullanılan TPU filaman ve baskılama sonucu üretilen yapay kulak kepçesine ait TGA analizleri Şekil 5' te gösterilmiştir. Sıcaklık artışılla birlikte TPU filamanda meydana gelen termal bozunmalar grafikte gösterildiği gibi iki aşamada kütle kaybına neden olmuştur. İlk aşama, $300^{\circ} \mathrm{C}-400^{\circ} \mathrm{C}$ aralı̆̆ında üretan bağlarının poliyol ve izosiyanata ayrışmasıyla gerçekleşmiştir. Ayrıca bu aşama en yoğun kütle kaybının yaşandığı bölgedir. İkinci aşamada ise $400^{\circ} \mathrm{C}-535^{\circ} \mathrm{C}$ aralığında poliyol bozunmaları meydana gelerek ağırlıkça yaklaşı \%15 kütle kayıpları yaşanmıștır [17-19]. Üretilen yapay kulak kepçesinde ise sıcaklık artışıyla birlikte üç aşamada kütle kayıpları gözlemlenmiştir. İlk olarak $300^{\circ} \mathrm{C}-425^{\circ} \mathrm{C}$ aralığında üretan bağlarının ayrışmasıyla en fazla kütle kayıpları meydana gelmiștir. Daha sonra, ester bağlarının $425^{\circ} \mathrm{C}-575^{\circ} \mathrm{C}$ aralığında bozunmasıyla birlikte kütle kayıpları devam etmiştir [20]. Son aşamada ise $575^{\circ} \mathrm{C}-635^{\circ} \mathrm{C}$ aralığında meydana gelen poliyol bozunmalarıyla kütle kayıpları yaşanmıştır [19]. TGA analizinde görüldüğü gibi gerçekleșen bu kütle kayıpları, üretilen yapay insan kulak kepçelerinin termal olarak 3B baskılamaya uygun olduğunu göstermektedir.

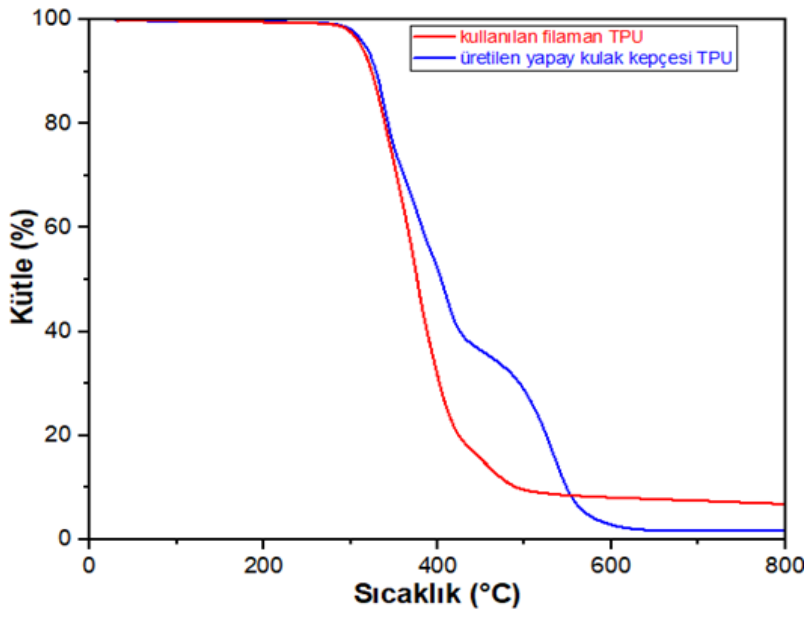

Şekil 5. Üç boyutlu baskılamada kullanılan polimere ve üretilen kulak kepçesine ait TGA grafiği

Kullanılan TPU filamanın sertlik değeri 50 Shore D, üretilen kulak kepçesinin sertlik değeri ise 63,5 Shore D olarak belirlenmiștir. Ölçüm için alınan numune parçalarının üç farklı noktasından alınan sertlik değerlerinin ortalamaları hesaplanmış ve standartlara uygun termoplastik malzemesi kullanıldığı belirlenmiştir [21]. 3B baskı üretimiyle sertlikte meydana gelen artış, baskı esnasında polimerin erime-soğuma döngüsü sonucunda yapısındaki kristalin bölgelerin artmasından kaynaklandığı düşünülmektedir.

TPU kulak kepçelerine ait çekme numunelerinin çekme testi sonuçları Şekil 6' da gösterilen gerilmeuzama eğrisinde sunulmuştur. Kalınlığı yaklaşık 2 mm olan çekme numulerine ait gerilme - yüzde uzama grafiği olușturulurken, farklı doluluk oranlarına sahip her bir kulak kepçesi örneği için üç ayrı çekme numunesi üretilerek ortalama sonuçları hesaplanmıştır. Elde edilen çekme dayanımı değerleri Tablo 3' te gösterilmiştir.

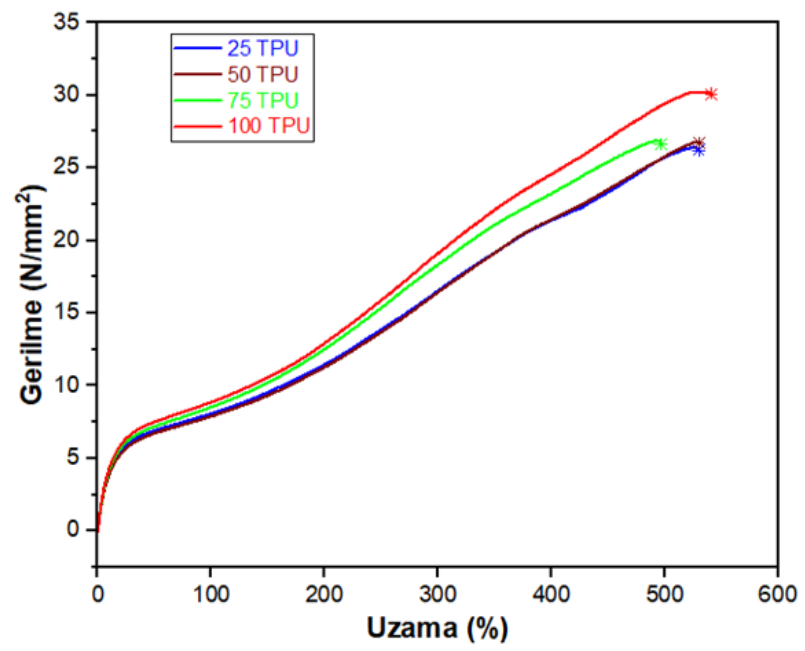

Şekil 6. Üç boyutlu yazıcı kullanılarak üretilen kulak kepçesi numunelerinin çekme testi grafiği 
Tablo 3. Elde edilen kulak kepçesi numunelerine ait çekme dayanımları

\begin{tabular}{ll}
\hline $\begin{array}{l}\text { Farklı doluluk oranındaki çekme } \\
\text { numuneleri }\end{array}$ & Çekme dayanımı \\
\hline$\% 25$ & $26,2 \mathrm{~N} / \mathrm{mm}^{2}$ \\
$\% 50$ & $26,7 \mathrm{~N} / \mathrm{mm}^{2}$ \\
$\% 75$ & $26,6 \mathrm{~N} / \mathrm{mm}^{2}$ \\
$\% 100$ & $30,1 \mathrm{~N} / \mathrm{mm}^{2}$ \\
\hline
\end{tabular}

Şekil 6 ve Tablo 3’ te görüldüğü gibi \%100 doluluk oranına sahip olan TPU en fazla çekme dayanımı sergilerken, \%25 doluluk oranındaki TPU en düşük çekme dayanımına sahiptir. Rastgele dağılmış sert ve yumuşak bölgelerden oluşan iki fazlı yapısı sayesinde kopolimer gibi mekaniksel özelliğe sahip TPU, FTIR sonuçlarından da görüldügü üzere mikro yapısındaki H-bağlarından ileri gelen fiziksel çapraz bağlara da sahiptir. Sert ve yumuşak bölgeler arasındaki bu bağlar malzemenin çekme dayanımı ve uzaması üzerinde önemli etkiye sahiptir [22,23]. 3B baskılama işleminde doluluk oranını arttırmak, TPU tabakaları arasındaki boşluğu azalttığı için katmanlar arası fiziksel birleşme eğilimi artmaktadır [6]. Yapılan testlerde doluluk oranı arttıkça çekme dayanımında az da olsa artış gözlemlenmiştir. Artan dolgu oranı ile çekme dayanımı değerlerinde kayda değer artışların olmaması, dolgu kısımların basma açılarının uygulanan kuvvet yönünde olmamalarından kaynaklandığı düşünülmektedir. Eğer dolgu basma açıları çekme kuvveti yönünde ya da yakın açılarsa seçilirse mekanik özelliklerde daha fazla artışlar beklenebilir. Ayrıca, yapay kulak numunelerine ait elde edilen çekme değerleri 3B baskılama işleminin tekrarlanabilirliğini de vurgulamaktadır.

Çekme testi uygulanan numunelerin enine ve boyuna kesitlerini görüntülemek için stereomikroskop kullanılmıştır. Farklı büyütmelerde ölçeklendirilen test numunelerinin kırık yüzeyleri Şekil 7' de gösterildiği gibi incelenmiștir. Numunelere ait bütün stereomikroskop görüntülerinde $3 \mathrm{~B}$ baskılamanın tabaka tabaka oluşturulduğu doğrulanmıştır. Kırılmanın gerçekleştiği bölgelerin, TPU yapısındaki yumuşak (amorf) polimer zincirlerinin yoğunlaştığı tabakalarda gerçekleştiği düşünülmektedir. Şekil 8' de ise aynı test numunelerinin yüzey görüntüleri SEM ile sergilenmiştir. Farklı doluluk oranlarına sahip TPU çekme örneklerinin katman kalınlıkları taramalı elektron mikroskobu görüntüleriyle desteklenmektedir. Ayrıca doluluk oranının artmasıyla birlikte, daha yoğun bir yapının ortaya koyulduğu, yapı içerisindeki boşluk miktarının azaldığı ve dolayısıyla kopma için gerekli çekme kuvvetinin daha yüksek olduğu SEM fotoğraflarından anlaşılabilmektedir. Dolayısıyla yapay kulak kepçelerine ait çekme test numunelerinin mikroskop görüntüleriyle protez kulak kullanımından ziyade, EYM prosesinde gerçekleşen üretimin tabaka tabaka yapıldığı vurgulanmıștır.
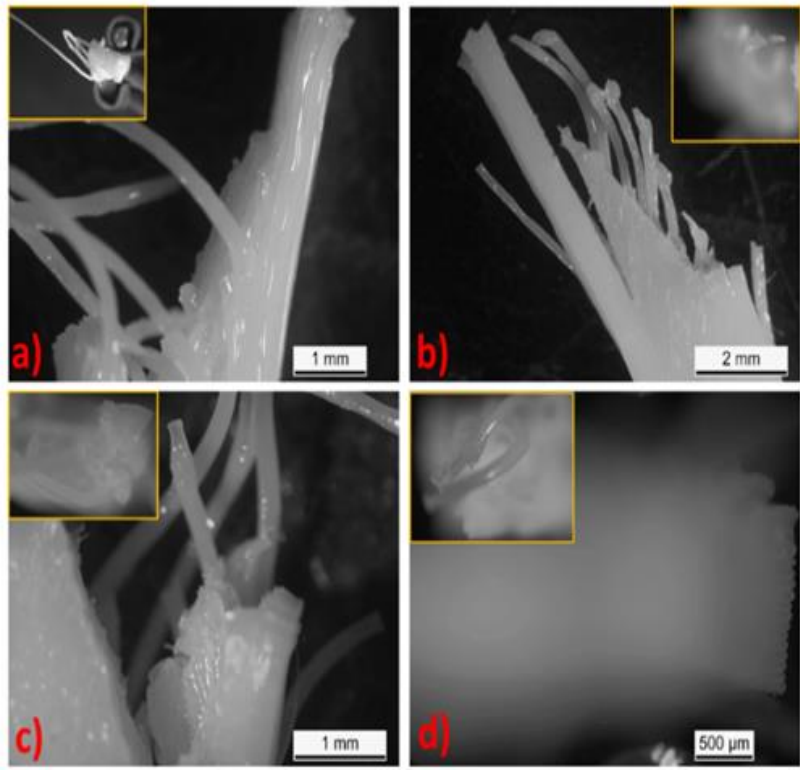

Şekil 7. 3B baskılama ile hazırlanan farklı doluluk oranlarındaki çekme numunelerinin stereomikroskop görüntüleri. (a) $\% 25$, (b) \%50, (c) $\% 75$ ve (d) $\% 100$
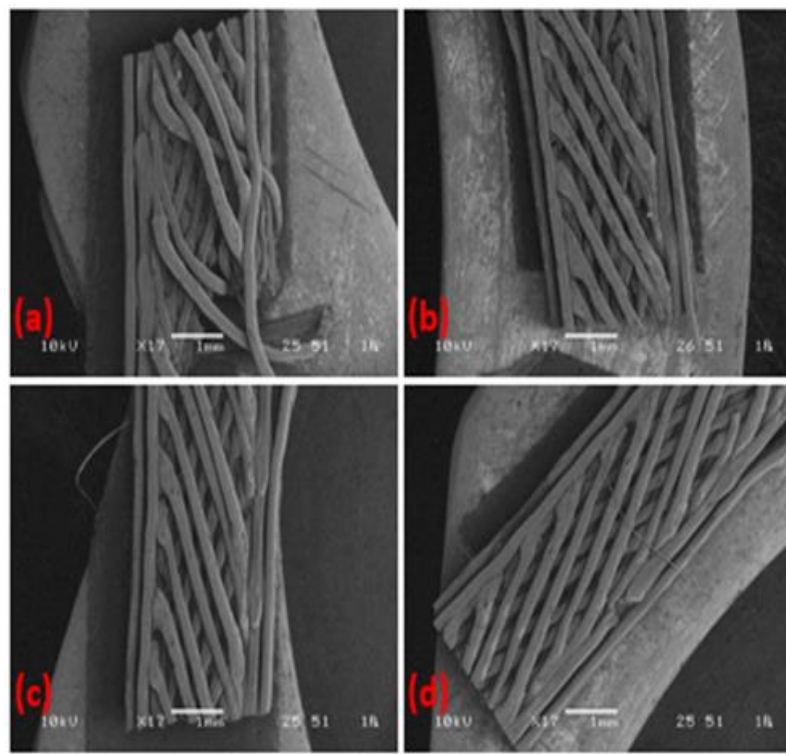

Şekil 8. 3B baskılama ile hazırlanan farklı doluluk oranlarındaki çekme numunelerinin SEM görüntüleri. (a) $\% 25$, (b) $\% 50$, (c) $\% 75$ ve (d) $\% 100$

\section{Tartışma ve Sonuç}

Bu çalışmada, geliştirilen yapay insan kulak kepçesi numuneleri EYM 3 boyutlu yazıcı tekniği kullanılarak başarılı bir şekilde üretilmiştir. Farklı doluluk oranlarında (\%25, \%50, \%75 ve \%100) üretilen kulak kepçesi numuneleri uygun proses parametreleri belirlenerek elde edilmiştir. 3B baskılama için kullanılacak olan TPU polimer malzemesinin kimyasal, termal ve mekanik olarak üretime uygun olduğu ve üretilen kulak kepçesi numunelerinin literatür bilgileriyle örtüştüğü FTIR, TGA ve sertlik analizleriyle tespit edilmiştir. Üretilen TPU kulak kepçelerinin görüntüleri incelendiğinde 
şekil ve dış yüzey görünümlerine bakılarak en uygun tasarımın doluluk oranı $\% 50$ olan numuneye ait olduğu anlaşılmıştır. Kulak kepçesi numunelerinin çekme dayanımlarını belirlemek için kulak üretiminde kullanılan proses parametreleri kullanılarak üç boyutlu baskılama tekniği ile üretilen test numuneleri kullanılmıștır. Artan doluluk oranıyla numunelerin çekme dayanımlarının arttığı gözlemlenmiştir. Aynı numunelerin stereomikroskop ve SEM görüntüleriyle 3B baskılamanın, belirlenen tabaka kalınlığı parametrelerinde katman katman gerçekleștiği kanıtlanmıștır. $\mathrm{Bu}$ çalıșmanın devamında, elde edilen yapay insan kulak kepçesi numunelerin protez olarak kullanımı belirlemek için toksisite ölçümleri ile antibakteriyel etki testleri yapılması düşünülmektedir.

\section{Kaynakça}

[1] Suaste-Gómez, E., Rodríguez-Roldán, G., ReyesCruz, H., Terán-Jiménez, 0. 2016. Developing an Ear Prosthesis Fabricated in Polyvinylidene Fluoride by a 3D Printer with Sensory Intrinsic Properties of Pressure and Temperature. Sensors, 16(3), 332-342.

[2] Park, C., Yoo, Y-S., Hong, S-T. 2010. An update on auricular reconstruction: Three major auricular malformations of microtia, prominent ear and cryptotia. Current Opinion in Otolaryngology \& Head and Neck Surgery, 18(6), 544-549.

[3] Mi, H-Y., Salick, M. R., Jing, X., Jacques, B. R., Crone, W. C., Peng, X-F., Turng, L-S. 2013. Characterization of thermoplastic polyurethane/polylactic acid (TPU/PLA) tissue engineering scaffolds fabricated by microcellular injection molding. Materials Science and Engineering C, 33(8), 4767-4776.

[4] Ngo, T. D., Kashani, A., Imbalzano G., Nguyen, K. T. Q., Hui, D. 2018. Additive manufacturing (3D printing): A review of materials, methods, applications and challenges. Composites Part B: Engineering, 143, 172-196.

[5] Bakar, N. S. A., Alkahari, M. R., Boejang, H. 2010. Analysis on fused deposition modelling performance. Journal of Zhejiang UniversitySCIENCE A (Applied Physics \& Engineering), 11(12), 972-977.

[6] Hohimer, C., Christ, J., Aliheidari, N., Mo, C., Ameli, A. 2017. 3D printed thermoplastic polyurethane with isotropic material properties. Proceeding of SPIE, Behavior and Mechanics of Multifunctional Materials and Composites, 10165(11), 277-286.

[7] Brenken, B., Barocio, E., Favaloro, A., Kunc, V., Pipes, R. B. 2018. Fused filament fabrication of fiber-reinforced polymers: A review. Additive Manufacturing, 21, 1-16.
[8] Zeng, W., Lin, F., Shi, T., Zhang, R., Nian, Y., Ruan, J., Zhou, T. 2008. Fused deposition modelling of an auricle framework for microtia reconstruction based on CT images. Rapid Prototyping Journal, 14(5) 280-284.

[9] Przybytek, A., Gubańska, I., Kucińska-Lipka, J., Janik, H. 2018. Polyurethanes as a Potential Medical-Grade Filament for Use in Fused Deposition Modeling 3D Printers - a Brief Review. FIBRES \& TEXTILES in Eastern Europe, 26, 6(132), 120-125.

[10] Chohan, J. S., Singh, R., Boparai, K. S., Penna, R., Fraternali, F. 2017. Dimensional accuracy analysis of coupled fused deposition modeling and vapour smoothing operations for biomedical applications.Composites Part B, 117, 138-149.

[11] Mohamed, O. A., Masood, S. H., Bhowmik, J. L. 2016. Optimization of fused deposition modeling process parameters for dimensional accuracy using I-optimality criterion. Measurement, 81, 174-196.

[12] Mohamed, O. A., Masood, S. H., Bhowmik, J. L. 2015. Optimization of fused deposition modeling process parameters: a review of current research and future prospects. Additive Manufacturing, 3(1), 42-53.

[13] Chung, M., Radacsi, N., Robert, C., McCarthy, E. D., Callanan, A., Conlisk, N., Hoskins, P. R., Koutsos, V. 2018. On the optimization of lowcost FDM 3D printers for accurate replication of patient-specific abdominal aortic aneurysm geometry. 3D Printing in Medicine, 4(2), 1-10.

[14] Ulağ, S., Kalkandelen, C., Oktar F. N., Uzun, M., Şahin, Y, M., Karademir, B., Arslan, S., Kılıç, O., Ekren, N., Gündüz, O. 2018. 3 Boyutlu Yazıcı ile Polikaprolakton/Kitosan/Hidrojel Bazlı Küçük Çaplı Yapay Damar Üretimi. 23. Biyomedikal Bilim ve Teknoloji Sempozyumu, 15-16 Aralık, İstanbul, 34 .

[15] Dong, Z., Li, Y., Zou, Q. 2009. Degradation and biocompatibility of porous nano hydroxyapatite/polyurethane composite scaffold for bone tissue engineering. Applied Surface Science, 255(12), 6087-6091.

[16] Lee, M., Koo, J., Ki, H., Lee, K. H., Min B. H., Lee, Y. C., Kim, J. H. 2017. Phase Separation and Electrical Conductivity of Nanocomposites Made of Ether-/Ester-based Polyurethane Blends and Carbon Nanotubes. Macromolecular Research, 25(3), 231-242.

[17] Han, B., Cheng, A., Ji, G., Wu, S., Shen, J. 2004. Effect of Organophilic Montmorillonite on Polyurethane/Montmorillonite Nanocomposites. Journal of Applied Polymer Science, 91(4), 25362542. 
[18] Petrović, Z. S., Javni, I., Waddon, A., Bánhegyi, G. 2000. Structure and Properties of PolyurethaneSilica Nanocomposites. Journal of Applied Polymer Science, 76(2), 133-151.

[19] Xia, H., Song, M. 2005 Preparation and characterization of polyurethane-carbon nanotube composites. Soft Matter, 1(5), 386394.

[20] Cangemi, J. M., Neto, S. C., Chierice, G. O., dos Santos, A. M. 2006. Study of the Biodegradation of a Polymer Derived from Castor Oil by Scanning Electron Microscopy, Thermogravimetry and Infrared Spectroscopy.
Polímeros: Ciência e Tecnologia, 16, (2), 129135.

[21] ASTM International. 2017. D2240-15 Standard Test Method for Rubber Property-Durometer Hardness, Planning Technology Inc, 13s. New Hampshire, ABD.

[22] Qi, H. J., Boyce, M. C. 2005. Stress-strain behavior of thermoplastic polyurethanes. Mechanics of Materials, 37(8), 817-839.

[23] Petrovic, Z. S., Ferguson, J. 1992. Polyurethane Elastomers. Progress in Polymer Science, 16(5), 695-836. 